\begin{tabular}{l|c|l}
\hline Biological and & Vol. 5(2): 315-319, 2021 & $\begin{array}{l}\text { ISSN: 2002-6153 } \\
\text { Biol. Appl. Environ. Res. } \\
\text { www.baerj.com } \\
\text { editor@ baerj.com }\end{array}$ \\
\hline
\end{tabular}

\title{
First Record of Apiosoma doliaris (Timofeev, 1962) Lom, 1966 (Ciliophora: Epistylidae) from Two Species of Fishes in Basrah Province, Iraq
}

\author{
Salem A.M. Al-Daraji \\ Department of Marine Biology, Marine Science Centre, University of Basrah, Basrah, Iraq \\ *Corresponding author: aldarajisalem@gmail.com

\begin{abstract}
The ciliophoran parasite Apiosoma doliaris (Timofeev, 1962) Lom, 1966 was detected from the gills of fry of both grass carp Ctenopharyngodon idella and common carp Cyprinus carpio during May 2018 at the ponds of Marine Science Centre Fish Hatchery, University of Basrah.. In the present study a brief description of $A$. doliaris was given. The occurrence of this species represents its first record in Iraq.
\end{abstract}

Keywords: Ciliophora, Apiosoma doliaris, Ctenopharyngodon idella, Cyprinus carpio, Iraq

\section{Introduction}

Hoffman (1970) stated that the protozoan parasites probably cause more diseases in fish culture than any other type group of animal parasites. Apiosoma species represent peritrichid ciliates belonging to the order Mobilida that live as ectocommensals on gills and body surfaces of aquatic organisms (Kahl, 1933).

These peritrichid ciliates are characterized taxonomically by possessing scopula as a substrate-attaching organ (Gong et al., 2006). Saville-Kent (1880-1881) described the first member of this genus under the name Spirochona tintinnabulum. After that, Bütschli (1889) separated this species from the genus Spirochona and renamed it as Glossatella tintinnabulum under his newly erected generic name. So, the term Glossatella was widely used for a long period. Apiosoma piscicola, a representative of the genus Apiosoma, was first found and named by Blanchard (1885) on Cyprinus carpio. Lom (1966) and Lynn (2008) gave the priority of the genus Apiosoma in their authoritative work. Li et al. (2008) summarized 72 species and one subspecies of Apiosoma. Shulman, (1987) described a new species of Apiosoma, i.e., A. applanatum from minnow Phoxinus phoxinus.

In Iraq, nine Apiosoma species were previously reported for the first time. These included A. piscicola from Ctenopharyngodon idella, Cyprinus carpio and Hypophthalmichthys molitrix by Ali et al. (1988), A. amoeba from both C. idella and $H$. molitrix by Ali et al. (1989), A. poteriformis from C. idella by Ali et al. (1989), A. minuta from C. carpio by Hussain (2007), A. robusta from Silurus triostegus by Shwani (2009), A. megamicronucleata from Planiliza abu (reported 
as Liza abu) by Al-Nasiri (2013), A. campanulata from Cyprinion kais by AlSalmany (2015), A. minicilata from Acanthobrama marmid by Al-Salmany (2015) and A. dollii from P. abu by Al-Musawi (2016). More fish host species were also reported for the above-named nine Apiosoma species (Mhaisen, 2021). Due to the shortage of our knowledge on the parasitic fauna of fishes reared in ponds of Marine Science Centre, the present article was designed to highlight on fish fry infection with A. doliaris, which is recorded here for the first time in Iraq and hence represents the tenth species of the genus Apiosoma in freshwater fishes of Iraq.

\section{Materials and Methods}

During the survey of fish parasites at the ponds of Marine Science Centre Fish Hatchery, University of Basrah, in May 2018, a total of 53 fry of grass carp Ctenopharyngodon idella and 87 fry of common carp Cyprinus carpio were examined for the parasites which may infect the fry and threaten their health and survival. Random samples of fry were collected by using small hand net and transferred to the laboratory of Parasites of Aquatic Animals; fry were kept temporarily in a 20liter water tank for further examination.

Samples of mucus were scraped from the skin, fins and gills of freshly killed fry and observed under a compound microscope. Some specimens of Apiosoma were smeared on cover slips, fixed in saturated $\mathrm{HgCl}_{2}$ solution and stained with Heidenhain or Ehrlich's haematoxylin (Li et al., 2008). Then, the drawing of the parasite was carried out with the aid of camera Lucida. All measurements were taken in micrometers. Peritrichid parasites were identified according to Shulman (1984).

\section{Results}

Under the compound microscope, a large numbers of A. doliaris were observed on gills of the infected fishes and the prevalence of infection with this parasite was $69.8 \%$ in C. idella and $70.1 \%$ in C. carpio.

\section{Description of the Parasite}

Based on ten specimens, the detected ciliate is somewhat elongated, barrel-like in shape and stalkless. Its body is gradually tapering from the equatorial region towards ciliated peristomial disc and scopula, showing a certain flexibility and some variations in form and size (Fig. 1). 


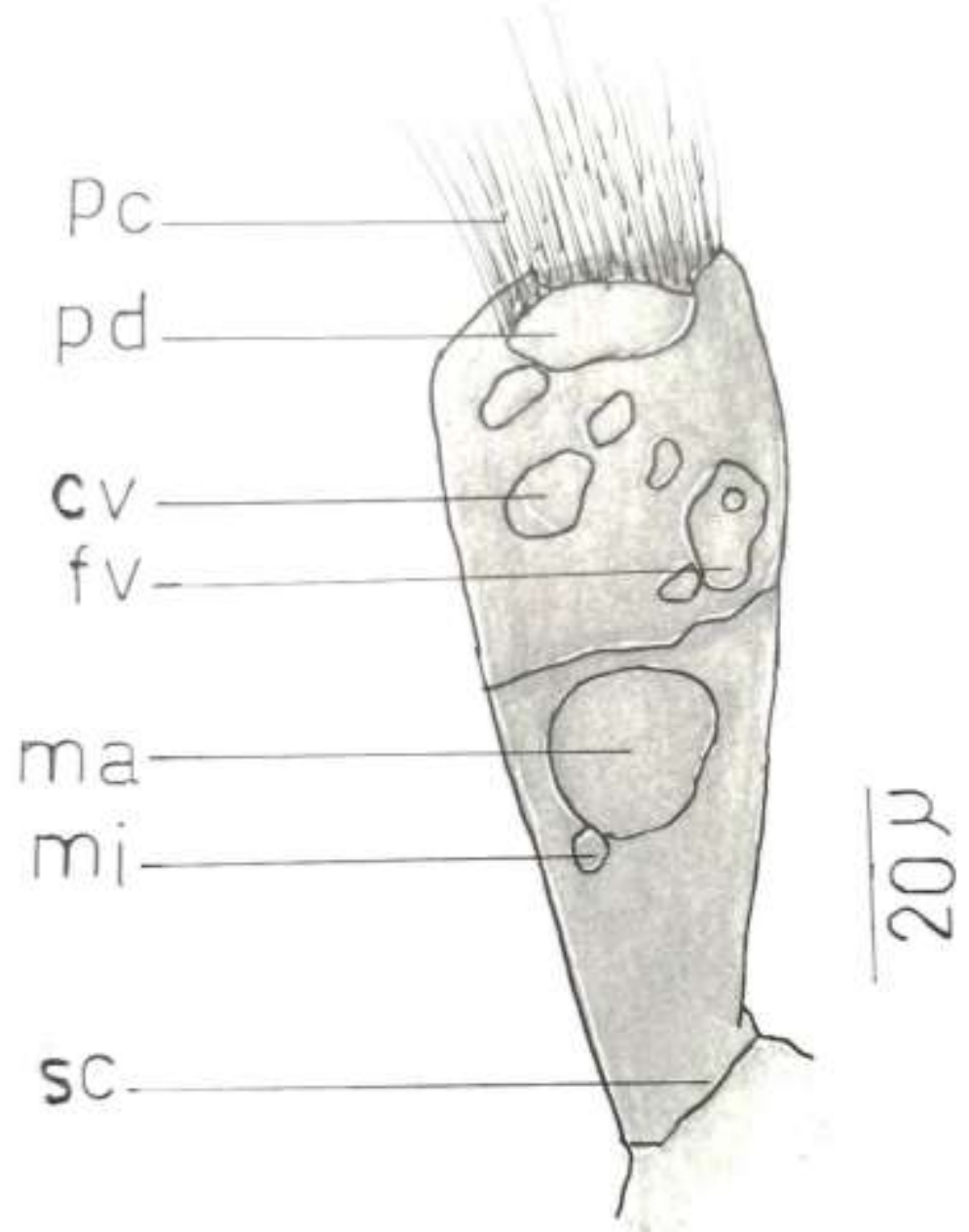

Figure 1: Apiosoma doliaris. cv, contractile vacuole; fv, food vacuole; man, macronucleus; min, micronucleus; pc, peristomial cilia; pd, peristomial disc; sc, scopula.

The measurements of fixed specimens ranged from 31.4 to 43.9 (38.3) $\mu \mathrm{m}$ in length and from 21.1 to 27.7 (24.2) $\mu \mathrm{m}$ in width. The body was divided by unciliated groove into two distinct portions: the oral portion which measuring 17.525.1 (21.4) $\mu \mathrm{m}$ in length and a basal portion measuring 13.9-18.8 (16.2) $\mu \mathrm{m}$ in length. The infundibulum extended towards the non-ciliated groove. The contractile and food vacuoles were usually distributed in the oral portion, whereas, the rounded macronucleus was situated below the groove in the basal portion and measuring 14.1-16.8 (15.1) $\mu \mathrm{m}$ in length and 13.7-15.5 (14.2) $\mu \mathrm{m}$ in width. Micronucleus was also rounded in shape and situated in the basal portion, adjacent to the macronucleus and measuring 1.5-2.3 (1.9) $\mu \mathrm{m}$ in diameter. The scopula is the holdfast organelle with its curved borders firmly attached to the host surface. It was broad, sucker-like disc with an undulant margin measuring 14.2-15.1 (14.6) $\mu \mathrm{m}$ in width. 


\section{Discussion}

Li et al. (2008) mentioned that the shape, size and positions of the nuclei are the most constant and important features to the specific identification of the genus Apiosoma. Also, they considered the body form and size of the living specimens of these ciliates crucial and necessary for specific identification besides 12 morphometric parameters; the body length and width, macronucleus length and width, micronucleus length and width, stalk length and width, diameter of peristome disc and transverse ciliary band, distance between peristome disc and macronucleus and transverse ciliary band.

In general, A. doliaris of the present investigation was closely similar to $A$. amoebae in its shape, but it distinctly defers from it in tapering mode, as the later species was gradually tapering from the tip of the body to the scopula while $A$. doliaris was gradually tapering just from the equatorial region towards the ciliated peristomial disc and scopula. In addition, A. amoebae has sometimes a ciliated equatorial girdle, whereas $A$. doliaris always has unciliated groove.

The present specimen of A. doliaris is closely resembling Shulman's (1984) specimens in its shape and measurements. Also, the present specimen appears a close similarity to El-Tantawy et al. (2013) specimens but its size was somewhat larger than the later one.

In Iraq, only nine species of the genus Apiosoma were previously recorded (Mhaisen, 2021). So, the present finding of A. doliaris represent the first record of this species and the tenth record of the genus Apiosoma infecting gills of the freshwater fishes in Iraq.

\section{References}

Ali, N.M.; Mhaisen, F.T. \& Abul-Eis, E.S. (1989). Three stalked ciliates (Scyphidia: Peritrichia) new to the parasitic fauna of the fishes of Iraq. Proc. $5^{\text {th }}$ Sci. Conf., Sci. Res. Counc., 5(2): 218-224.

Ali, N.M.; Salih, N.E. \& Abdul-Ameer, K.N. (1988). Protozoa and Crustacea infesting three species of carp raised in ponds in Iraq. J. Biol. Sci. Res., 19(2): 387-394.

Al-Musawi, A.M.K. (2016). Epidemiological study of external parasites that parasitic on Planiliza $a b u$ in three different habitats in the Province of Babylon. M. Technol. Thesis, Al-Musaib Tech. Coll., Al-Furat Al-Awsat Tech. Univ.: 126 pp. (In Arabic).

Al-Nasiri, F.S. (2013). Protozoan parasites of five fish species from the Tigris River in Salah Al-Deen Province, Iraq. J. Tikrit Univ. Agric. Sci., 13(1): 355-359.

Al-Salmany, S.O.K. (2015). Parasitic infections of some fish species from Euphrates River at Al-Qaim city, Anbar Province. M. Sc. Thesis, Coll. Sci., Univ. Tikrit: 193 pp. (In Arabic).

Blanchard, R. (1885). Sur un infusoire peritriche, ectoparasite des poissons d'eau douce. Bull. Soc. Zool., France, 10: 277-280. 
Bütschli, O. (1889). Protozoa. Abt. III. Infusoria und system der radiolaria. In: Bronn, H.G. (ed.). Klassen und Ordnungen des Their-Reichs I.C.F. Winter, Leipzig: 1098-2035.

El-Tantawy, S.A.M.; Reda, E.S.A.; Abdel-Aziz, A.; Abou El-Nour, M.F. \& Rady, I. (2013). Apiosoma spp. and Scopulata epibranchialis infesting Nile perch fish Lates niloticus in Dakahlia Province, Egypt. New York Sci. J., 6(6): 111118.

Gong, Y.-C.; Yu, Y.-H.; Villalobo, E.; Zhu, F.-Y. \& Miao, W. (2006). Reevaluation of the phylogenetic relationship between mobilid and sessilid peritrichs (Ciliophora, Oligohymenophorea) based on small subunit rRNA genes sequences. J. Eukaryot. Microbiol., 53(5): 397-403. DOI:10.1111/j.15507408.2006.00121.x.

Hoffman, G.L. (1970). Parasites of North American freshwater fishes. Univ. California Press: 486 pp.

Hussain, H.T. (2007). Survey of ectoparasites of some fishes of Al-Hilla River in Babylon Province. J. Babylon Univ., Sci., 14(3): 228-232. (In Arabic).

Kahl, A. (1933). Ciliata libera et ectocommensalia. In: Grimpe, G. \& Wagler, E (eds.). Die tierwelt der Nord-und Ostee. Lief. 23 (Teil II, C3), Leipzig: 29146.

Li, M.; Wang, J.; Zhu, D.; Gu, Z.; Zhang, J. \& Gong, X. (2008). Study of Apiosoma piscicola (Blanchard, 1885) occurring on fry of freshwater fishes in Hongze, China with consideration of the genus Apiosoma. Parasitol. Res., 102: 931937. DOI: 10.1007/s00436-007-0856-5.

Lom, J. (1966). Sessiline peritrichs from the surface of some freshwater fishes. Fol. Parasitol. (Praha), 13(1): 36-56.

Lynn, D.H. (2008). The ciliated protozoa: Characterization, classification and guide to the literature, $2^{\text {nd }}$ edition. Springer, Dordrecht: 605 pp. DOI: $10.1007 / 978-$ 1-4020-8239-9.

Mhaisen, F.T. (2021). Index-catalogue of parasites and disease agents of fishes of Iraq. (Unpublished: mhaisenft@ yahoo.co.uk)

Saville-Kent, W. (1880-1881). A manual of the Infusoria, including a description of all known flagellate, ciliate, and tentaculiferous protozoa, British and foreign and an account of the organization and affinities of the sponges. David Bogue, London. DOI:10.5962/bhl.title.1243.

Shulman, B.S. (1987). A new species of Ciliophora (Peritricha, Epistylidae) Apiosoma applanatum sp. $\mathrm{n}$. from the minnow. Parazitologiya (Leningr.), 21(3): 508-510.

Shulman, S.S. (1984). Parasitic Protozoa. In: Key to the parasites of freshwater fish fauna of the U.S.S.R. Nauka, Leningrad, 1: 1-428. (In Russian).

Shwani, A.A.A. (2009). The parasitic fauna of Asian catfish Silurus triostegus (Heckel, 1843) from Greater Zab River- Kurdistan Region- Iraq. M. Sc. Thesis, Coll. Sci. Educ., Univ. Salahaddin: 75 pp. 